\title{
EXPLOITATION OF MULTIPLE APPROACHES TO ADAPT AND MITIGATE THE NEGATIVE EFFECTS OF HEAT STRESS ON MILK PRODUCTION AND FERTILITY OF FRIESIAN COWS UNDER FIELD CONDITIONS
}

\author{
ASMAA N. MOHAMMED*; R.L. ABDEL AZIZ ${ }^{* *}$ and M.M.A. ZEINHOM ${ }^{* * *}$ \\ *Department of Hygiene, Management and Zoonoses, Faculty of Veterinary Medicine, Beni-Suef University, Beni-Suef, \\ Egypt. \\ ${ }^{* *}$ Department of Theriogenology, Faculty of Veterinary Medicine, Beni-Suef University, Beni-Suef, Egypt. \\ **** Department of Food Hygiene and Control, Faculty of Veterinary Medicine, Beni-Suef University, Beni-Suef, Egypt.
}

Email: asmade182@yahoo.com, asmaa.mohamed2@vet.bsu.edu.eg Assiut University web-site: www.aun.edu.eg

ABSTRACT

Received at: $20 / 8 / 2015$

This study was designed to assess impact of heat stress on performance of low producing Friesian cows and implement adaptive herd management including

Accepted: 15/9/2015 multiple approaches for alleviate these impacts. The Temperature Humidity Index (THI) and physiological parameters (cow's rectal temperature 'RT' and respiration rate 'RR') were used as indicators of heat stress. Daily averages of microclimatic factors in district were recorded; milk production data were recorded throughout study period. Postpartum cyclicity and reproductive parameters were estimated. Finally, a field trial based on multiple approaches to mitigate impacts of heat stress was planned and implemented. Results, mTHI $>78$ significantly $(\mathrm{P}<0.0001)$ increased $\mathrm{RR}$ and $\mathrm{RT}$ and decreased average daily milk/cow $(\mathrm{P}<0.0001)$. Moreover, mTHI $>78$ was associated with significantly lower cyclicity by 60 days postpartum, cyclic high progesterone (P4) and first insemination conception, compared to $\mathrm{mTHI}<72$. Interestingly, serum P4 levels five days post insemination were negatively correlated $(\mathrm{r}=-0.88, \mathrm{P}<0.0001)$ with mTHI. Furthermore, mTHI $>78$ significantly $(\mathrm{P}<0.001)$ increased days to first estrus and days to conception (days open). Also, cows exposed to $\mathrm{mTHI}<72$ and $72-78$ acquired significantly $(\mathrm{P}<0.01)$ fewer inseminations per conception, as compared to cows exposed to mTHI $>78$. The field trial implemented decreased cows' physiological parameters, increased their milk and increased serum P4 concentrations of pregnant cows Subjected to adaptive measures. Conclusion, heat stress negatively impacted milk production and fertility of low producing Friesian cows with significant impacts observed with mTHI above 78. Implementation of adaptive measures led to increased milk production of adapted cows and increased serum $\mathrm{P} 4$ in pregnant cows.

Key words: THI, Friesian cows, Milk yield, Fertility, Adaptive measures

\section{INTRODUCTION}

Heat stress is all temperature-related forces that encourage changes or adjustments which may occur from the cellular to the total animal level to help the cows stay away from physiological disorders and to adapt to an adverse thermal environment (Kadzere et al., 2002). Climate can affect livestock both directly and indirectly (Adams et al., 1999; McCarthy et al., 2001). Direct effects influence animal performance such as growth, milk production and reproduction. Economic loss due to heat stress is higher in dairy cattle compared to any other livestock species (Pierre et al., 2003).
In many developing countries, ambient temperature above $30^{\circ} \mathrm{C}$ may last for 6 months. This is important because approximately one third of the cattle population in the world is located in arid zones, and according to Intergovernmental Panel on Climate Change predictions, the global average surface temperature may increase between 1.8 and $4{ }^{\circ} \mathrm{C}$ by year 2100 (IPCC, 2007). So that the events feed intake, milk yield, as well as fertility rate are reduced (West, 2003). Temperature-humidity index (THI) is considered the most used stress index for use in animal husbandry (West et al., 2003) and is currently the most widely-accepted thermal index used for 
guidance of strategic decisions in animal management during moderate to hot conditions (Hahn et al., 2003; Hisashi et al., 2011).

Options assisting to minimize heat stress include housing and facilities adjustments. Also, environmental modifications that help to alleviate heat stress problems are structure orientation, structure ventilation, use of shades, and use of cooling systems in different sections of the dairy farm (Armstrong, 1994) in order to maintain milk production, reproductive performance and animal welfare. Reports on effects of climatic stress on performance of dairy cows in tropical and subtropical regions were targeted toward high producing cows with paucity of information on medium and low producing cows. Thus, the present study was conducted to assess impacts of heat stress on physiological responses, cyclicity and P4 concentrations and indicators of reproductive performance of low producing Friesian cows and to evaluate beneficial effects of implementation of adaptive measures including multiple approaches for efficient mitigation of these impacts.

\section{MATERIALS and METHODS}

Study area and period: This study was conducted in private Friesian herd during the period from June, 2013 and May, 2014 at Beni-Suef province. The climate is dry with low rainfalls during winter and sometimes study area is exposed to some hot blowing dust-laden wind during the period between March and June known as the Khamasine depressions (Hasanean, 2008).

Study design: A pilot study was carried out to assess impact of heat stress on milk yield and fertility of Friesian cows whereas THI, RT and RR were used as indicators to the degree of heat stress. Daily averages of Amp. Temp, relative humidity (RH) and air speed were recorded throughout study period. Data related to milk production were recorded. Postpartum cyclicity and indicators of reproductive performance were estimated and finally field trial to mitigate the impact of heat stress on cows was planned and implemented.

Animal population and management: This study was carried out on 124 Frisian cows kept separately in partially sheltered yards with earthy floor; allowing nine $\mathrm{m}^{2} / \mathrm{cow}$ during the daylight. Animals were transferred into a double range byre with concrete floor during the night. Water was provided from public sources for drinking, cleaning and washing before milking. Manure and soiled bedding were removed once every six months. Cows were milked twice daily on 6:00 AM and 18:00 PM using an automatic milking parlour.
Determination of Heat stress: THI, RT and RR were used for determination of heat stress, whereas the daily average of Amp. Temp and RH were recorded (three times daily) using clock thermohygrometer [Model 302, measuring range $\left(-20.0{ }^{\circ} \mathrm{C}\right.$ : $\left.\left.50.0{ }^{\circ} \mathrm{C}\right)\right]$ and $(20.0: 90.0 \%)$ under shade and located about 1.5 meters above the ground, meanwhile, air speed was measured by using digital anemometer [(Van E probe microprocessor digital meter) $\mathrm{n}$ 233569 , accuracy $-+2.0 \%+1.0 \mathrm{~d}$, resolution $0 \%$ ]

Calculation of THI: The mean value of THI was calculated by using the maximum of the daily temperature $\left(\mathrm{T}_{\max }{ }^{\circ} \mathrm{C}\right)$ and the minimum of the daily $\mathrm{RH}\left(\mathrm{RH}_{\min } \%\right)$ values, according to the following equation reported by Vitali et al. (2009).

$$
\begin{aligned}
& \mathrm{THI}_{\mathrm{Ra}}=\left(1.8 \times \mathrm{T}_{\max }{ }^{\circ} \mathrm{C}+32\right)-(0.55-0.0055 \times \\
& \left.\mathrm{RH}_{\min } \%\right) \times\left(1.8 \times \mathrm{T}_{\text {max }}{ }^{\circ} \mathrm{C}-26\right)
\end{aligned}
$$

THI values of 72 or less were considered comfortable, 72 to 78 were considered stressful, and values greater than 78 were considered as the cause of extreme distress (Kadzere et al., 2002).

Determination of physiological parameters: Both RR and RT of cows were recorded daily after milking and before feeding. RR were obtained by visually observing and counting flank or rib cage movements of cows over a 1-min period of uninterrupted breathing, meanwhile, RT were obtained by inserting a veterinary thermometer approximately $80 \mathrm{~mm}$ into the rectum for a period of 60 second recording readings to two decimal points which is expressed as an increase of $\mathrm{T}_{\text {rec }}$ above a level of $38.3^{\circ} \mathrm{C}$. (Sartori et al., 2002).

Postpartum cyclic status and P4 levels: Ten milliliters Jugular blood samples were obtained from each cow at 50 and 60 days postpartum (Ozturk et al., 2010). Serum was harvested by centrifugation at 1600 $\mathrm{g}$ for $15 \mathrm{~min}$ and was kept in Epindorff tubes at -20 ${ }^{\circ} \mathrm{C}$ till being assayed for P4. Serum P4 concentration was analyzed by RIA (Immulite, Siemens). The sensitivity of the assay was $0.46 \mathrm{ng} / \mathrm{mL}$. Cows with P4 concentration $\geq 1 \mathrm{ng} / \mathrm{mL}$ in one of the two samples were considered to have initiated cyclicity by 60 days postpartum. Cows having $\mathrm{P} 4$ concentration $\geq 1 \mathrm{ng} / \mathrm{mL}$ in the second samples were classified as cyclic high P4 cows (active CL), while those having P4 concentrations $<1 \mathrm{ng} / \mathrm{mL}$ in the second sample were classified as cyclic low P4 cows (Ozturk et al., 2010).

Reproductive management and indicators of reproductive performance: The voluntary waiting period of the herd was 60 days. Estrus was detected visually three times daily $-30 \mathrm{~min}$ each - by experienced farm workers. Cows were inseminated $12 \mathrm{hr}$ after the first observed standing heat. Pregnancy was diagnosed at 45 day after insemination by trans- 
rectal examination of the uterus. Conception rate to first insemination was calculated as the number of cows diagnosed pregnant after first insemination divided by the total number of inseminated cows (Ouweltjes et al., 1996).

Field trial to mitigate the impact of heat stress in dairy cows

Characters of selected cows: Forty eight cows were selected from herd irrespective of their age and lactation stage and were divided into two groups (each has 24 cows). Average time elapsed between conception and experiment was $4.53 \pm 0.49$ months in cows subjected to adaptive measures and $4.71 \pm 0.31$ months in control cows sampled for P4.

Study design: A field trial was carried out between 15 September and 15 October 2013.Cows in Control group didn't receive any adaptive measures. Cows in experimental group received the following adjustment: A stocking rate of twelve $\mathrm{m}^{2} /$ cow, shade area with high, well ventilated roof at three and half meter height, evaporative cooling (overhead water sprinkling and forced ventilation) in the holding area adjacent to the milking parlor twice daily before milking each for $30 \mathrm{~min}$ ), daily water intake was increased from 15 to 40 gallons/cow and once weekly removal of organic matter to reduce the emission of gases. RT and RR of adapted dairy cows were measured daily before and after control measures for each cow immediately after ten min in the chosen area, throughout the 30 day period of the trial, while average daily milk yield of subjected and control cows was obtained from daily farm records. Weekly serum samples were obtained from a chosen pregnant group from both adapted and control cows to be assayed for P4 concentrations. Average serum P4 concentrations were $4.93 \pm 0.32$ and $4.09 \pm 0.41 \mathrm{ng} / \mathrm{mL}$, respectively in adapted and control cows in the week before application of the trial.

Statistical analysis: Data were statistically processed using (SPSS, 2007) software. Analysis of variance was used to test significance between THI classes. Student's t test was used to test significance between adapted and control cows. Chi square test was used to test significance between proportions. Significance was declared at $\mathrm{P}<0.05$.

\section{RESULTS}

As depicted in (Table 1) the highest mean values of Amp. Temp $\left(36.20 \pm 0.51^{\circ} \mathrm{C}\right)$ were recorded during August and decreased gradually to reach a minimum of 20.34 $\pm 0.73{ }^{\circ} \mathrm{C}$ during February. Meanwhile, fluctuation in mean values of RH was demonstrated as months of February, December, January $(64.50 \pm 1.86, \quad 63.08 \pm 2.40$ and $58.94 \pm 1.45 \%$, respectively) followed by those in November, October and September $(53.93 \pm 2.38,40.55 \pm 1.66$ and $40.10 \pm 0.77 \%$, respectively). On the other hand, the highest mean values of mTHI were recorded during August, July, June and September (81.42 \pm 0.65 , $80.63 \pm 0.57,80.00 \pm 0.68$ and $78.8 \pm 0.55$, respectively) followed by October and November $(75.36 \pm 0.58$ and $74.57 \pm 0.89$, respectively). Results cleared that average Amp. Temp was higher than the upper critical temperature $\left(20^{\circ} \mathrm{C}\right)$ for dairy cattle.

According to (Table 2) RT $\left(39.19{ }^{\circ} \mathrm{C}\right)$ was significant ( $\mathrm{P}<0.001)$ and negatively correlated with higher mTHI (>78), as compared to 38.06 and $38.77{ }^{\circ} \mathrm{C}$ at $\mathrm{mTHI}<72$ and $72-78$, respectively. However, RR was more sensitive to THI changes, with cows exposed to mTHI $72-78$ and $>78$ having significantly $(\mathrm{P}<0.0001)$ increased RR (53.72 and $65.61 \mathrm{~b} / \mathrm{m}$, respectively), as compared to those exposed to $\mathrm{mTHI}<72(32.14 \mathrm{~b} / \mathrm{m})$.

Referring to milk production (Table 2) daily average yield/cow ( $\mathrm{P}<0.0001)$ and total yield/group/day ( $\mathrm{P}$ $<0.001)$ were significantly lower in cows exposed to mTHI>78 (9.83 and $380.80 \mathrm{Kg}$, respectively), as compared to 11.12 and $422.43 \mathrm{Kg}$ in cows exposed to $\mathrm{mTHI}<72 ; 10.77$ and $409.13 \mathrm{Kg}$ in cows exposed to mTHI 72-78, respectively.

Regarding, indicators of reproductive performance, mTHI>78 significantly $(\mathrm{P}<0.001)$ increased days to first estrus (86.13 days), compared to 43.51 and 57.19 days at $\mathrm{mTHI}<72$ and $72-78$, respectively. Though, days to first insemination were only significantly ( $P$ $<0.001)$ increased from 55.79 days at $\mathrm{mTHI}<72$ to 93.44 days at mTHI>78. Moreover, days open were significantly increased at mTHI $>78$ (175.21 days), compared to 113.47 days at $\mathrm{mTHI}<72$ and 124.31 days at mTHI 72-78. Similarly, cows exposed to THI $>78$ acquired significantly higher number of inseminations to conceive $(5.53 \pm 0.82)$, in comparison to $(3.25 \pm 0.28$ and 3.38$)$ inseminations in cows exposed to $\mathrm{mTHI}<72$ and $72-78$, respectively as shown in (Table 2).

Postpartum cyclicity and conception were negatively affected by higher mTHI as indicated in (Table 3). Cows exposed to $\mathrm{mTHI}<72$ had significantly highercyclicity by 60 days postpartum (77.50\%), cyclic high P4 (80.65\%) and first insemination conception $(42.11 \%)$ and significantly lower cyclic low P4 (19.35\%), when compared to cows exposed to mTHI>78 (40.00, 25.00, 11.76 and 75.00\%; respectively). Moreover, cows exposed to mTHI 7278 did not vary significantly from the previous two variables although their cyclicity was depressed, in comparison with cows exposed to $\mathrm{mTHI}<72$.

Interestingly, a linear relationship $\left(\mathrm{R}^{2}=0.77\right)$ and a strong negative correlation $(\mathrm{r}=-0.88, \mathrm{P}<0.0001)$ 
between mTHI and serum concentrations of $\mathrm{P} 4$ obtained at five days after insemination were observed in examined cows.

Data presented in (Table 4) cleared that mean values of RT and RR of experimental cows presented a gradually increasing significant reduction throughout the four weeks of the experiment whereas in $4^{\text {th }}$ week they were $\left(38.37^{\circ} \mathrm{C}\right.$ and $43.27 \mathrm{~b} / \mathrm{M}$, respectively) as compared to control cows $\left(38.89^{\circ} \mathrm{C}\right.$ and $54.38 \mathrm{~b} / \mathrm{M}$, respectively).

As indicated in (Table 5) average and total milk yield of adapted cows/day throughout the $1^{\text {st }}$ week of experiment were significantly $(\mathrm{P}<0.01)$ higher $(11.31$ and $271.50 \mathrm{~kg} /$ day, respectively), as compared to control cows (8.17 and $196.00 \mathrm{~kg} /$ day, respectively). Adapted cows, then, maintained an increasing significantly higher average yield per cow and total yield per group throughout the $2^{\text {nd }}, 3^{\text {rd }}$ and $4^{\text {th }}$ weeks of the trial. Additionally, in (Table 6) an increased serum P4 concentration was observed in adapted pregnant cows, when compared to control cows with increases becoming significant on the third and fourth weeks of the trial. Serum P4 concentrations were 4.06 vs. $4.46,5.23$ vs. $4.65,6.45$ vs. 4.67 and 6.34 vs. $5.06 \mathrm{ng} / \mathrm{mLfor}$ week $1,2,3$ and 4 in adapted and control cows, respectively. Furthermore, the overall mean concentration of serum $\mathrm{P} 4$ was significantly higher $(\mathrm{P}<0.01)$ in adapted cows $(5.52)$, as compared to $4.71 \mathrm{ng} / \mathrm{mLin}$ control cows.

Table 1: The Mean values $( \pm S E)$ of ambient temperature, relative humidity, air speed and mean TemperatureHumidity Index (mTHI) in dairy farm throughout study period.

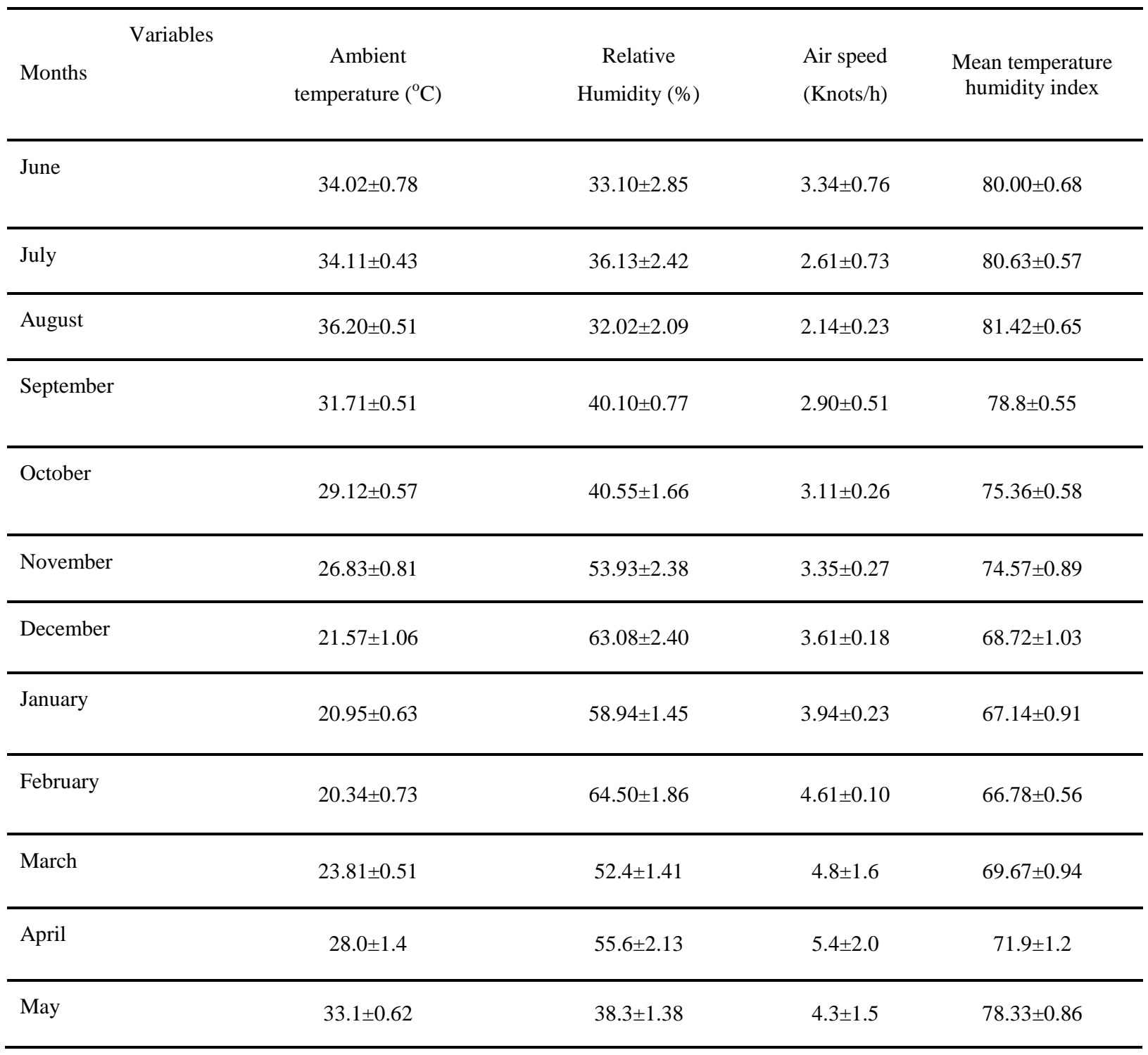


Table 2: Physiological responses, milk production and reproductive performance of low producing Friesian cows in response to temperature-Humidity Index (THI) variables.

\begin{tabular}{|c|c|c|c|c|c|}
\hline \multirow{2}{*}{ Parameters } & \multicolumn{3}{|c|}{ THI variables } & \multirow{2}{*}{ RSD } & \multirow{2}{*}{$\mathrm{P}$ value } \\
\hline & $<72$ & $72-78$ & $>78$ & & \\
\hline \multicolumn{6}{|l|}{ Physiological parameters } \\
\hline $\mathrm{RT}\left({ }^{0} \mathrm{C}\right)$ & $38.06 \pm 0.08^{\mathrm{a}}$ & $38.77 \pm 0.07^{\mathrm{a}}$ & $39.19 \pm 0.12^{b}$ & 1.01 & 0.0001 \\
\hline $\mathrm{RR}(\mathrm{b} / \mathrm{m})$ & $32.14 \pm 0.84^{\mathrm{a}}$ & $53.72 \pm 0.61^{\mathrm{b}}$ & $65.61 \pm 0.72^{\mathrm{b}}$ & 6.20 & $<0.0001$ \\
\hline \multicolumn{6}{|l|}{ Daily milk yield (Kg) } \\
\hline Average per cow & $11.20 \pm 0.19^{\mathrm{a}}$ & $10.77 \pm 0.07^{\mathrm{a}}$ & $9.83 \pm 0.20^{\mathrm{b}}$ & 2.08 & $<0.0001$ \\
\hline Total per group & $422.43 \pm 7.33^{\mathrm{a}}$ & $409.13 \pm 2.67^{\mathrm{a}}$ & $380.8 \pm 3.80^{\mathrm{b}}$ & 21.60 & 0.0001 \\
\hline \multicolumn{6}{|l|}{ Reproductive performance } \\
\hline Days to first estrus & $43.51^{\mathrm{a}} \pm 5.83$ & $57.19^{\mathrm{a}} \pm 7.39$ & $86.13^{\mathrm{b}} \pm 6.91$ & 17.53 & 0.0001 \\
\hline Days to first AI & $55.79^{\mathrm{a}} \pm 5.13$ & $68.85^{\mathrm{ab}} \pm 9.11$ & $93.44^{\mathrm{b}} \pm 7.04$ & 17.54 & 0.0007 \\
\hline Days to conception & $113.47^{\mathrm{a}} \pm 9.23$ & $124.31^{\mathrm{a}} \pm 11.02$ & $175.2^{\mathrm{b}} \pm 10.20$ & 22.39 & 0.0003 \\
\hline NIPC & $3.25^{\mathrm{a}} \pm 0.28$ & $3.38^{\mathrm{a}} \pm 0.49$ & $5.53^{\mathrm{b}} \pm 0.82$ & 1.25 & 0.0032 \\
\hline
\end{tabular}

$\mathrm{RT}=$ Rectal Temperature; RR=Respiratory Rate; $\mathrm{b} / \mathrm{m}=$ breath per minute; $\mathrm{AI}=$ Artificial Insemination; NIPC=Number of Inseminations per Conception; RSD=Residual Standard Deviation.

$\mathrm{a}-\mathrm{b}$ Within a row, means without a common superscript letter differ $(\mathrm{P}<0.05)$.

Table 3: Postpartum cyclicity, Serum progesterone levels in cyclic animals and first insemination conception of low producing Friesian cows in response to Temperature-Humidity Index (THI) variables.

\begin{tabular}{lccc}
\hline Cyclicity and conception & \multicolumn{2}{l}{ THI variables } \\
\hline & $<72$ & $72-78$ & $>78$ \\
\hline Cyclic cows by 60 days postpartum n $(\%)$ & $31\left(77.50^{\mathrm{b}}\right)$ & $13\left(65.00^{\mathrm{ab}}\right)$ & $8\left(40.00^{\mathrm{a}}\right)$ \\
\hline Cyclic high progesterone $^{1} \mathrm{n}(\%)$ & $25\left(80.65^{\mathrm{b}}\right)$ & $7\left(53.84^{\mathrm{ab}}\right)$ & $2\left(25.00^{\mathrm{a}}\right)$ \\
\hline Cyclic low progesterone $^{2} \mathrm{n}(\%)$ & $6\left(19.35^{\mathrm{a}}\right)$ & $6\left(46.16^{\mathrm{ab}}\right)$ & $6\left(75.00^{\mathrm{b}}\right)$ \\
\hline First insemination conception $\mathrm{n}(\%)$ & $16 / 38\left(42.11^{\mathrm{b}}\right)$ & $5 / 15\left(33.33^{\mathrm{ab}}\right)$ & $2 / 17\left(11.76^{\mathrm{a}}\right)$ \\
\hline
\end{tabular}

$\mathrm{N}=$ Number of animals.

${ }^{1}$ cyclic cows in which serum progesterone level in the second sample was more than $1 \mathrm{ng} / \mathrm{ml}$.

${ }^{2}$ cyclic cows in which serum progesterone level in the second sample was less than $1 \mathrm{ng} / \mathrm{ml}$.

$\mathrm{a}-\mathrm{b}$ Within a row, means without a common superscript letter differ $(\mathrm{P}<0.05)$.

Table 4: Physiological parameters of low producing Friesian cows in response to control measures to alleviate heat stress.

\begin{tabular}{|c|c|c|c|c|}
\hline Physiological parameter & Before cooling & After cooling & RSD & $\mathrm{P}$ value \\
\hline \multicolumn{5}{|l|}{ RT } \\
\hline $1^{\text {st }}$ week & $38.75 \pm 0.11$ & $38.30 \pm 0.10$ & 0.26 & 0.020 \\
\hline $2^{\text {nd }}$ week & $38.95 \pm 0.12$ & $38.53 \pm 0.13$ & 0.11 & 0.060 \\
\hline $3^{\text {rd }}$ week & $39.09 \pm 0.12$ & $38.66 \pm 0.11$ & 0.17 & 0.010 \\
\hline $4^{\text {th }}$ week & $38.71 \pm 0.03$ & $38.37 \pm 0.03$ & 0.10 & $<0.0001$ \\
\hline \multicolumn{5}{|l|}{ RR } \\
\hline $1^{\text {st }}$ week & $56.00 \pm 0.99$ & $47.34 \pm 0.97$ & 1.28 & 0.028 \\
\hline $2^{\text {nd }}$ week & $53.12 \pm 0.62$ & $44.11 \pm 0.78$ & 0.74 & 0.002 \\
\hline $3^{\text {rd }}$ week & $60.61 \pm 0.77$ & $50.00 \pm 0.74$ & 1.48 & 0.001 \\
\hline $4^{\text {th }}$ week & $54.38 \pm 0.65$ & $43.27 \pm 0.87$ & 1.97 & 0.001 \\
\hline
\end{tabular}

RT=Rectal Temperature; RR=Respiratory Rate; RSD=Residual Standard Deviation. 
Table 5: Milk yield of low producing Friesian cows in response to control measures to alleviate heat stress.

\begin{tabular}{lcccc}
\hline Milk yield & Control group & Adapted group & RSD & P value \\
\hline Average daily milk per cow (Kg) & & & & \\
One week before trial & $9.86 \pm 0.82$ & $10.42 \pm 0.21$ & 1.49 & 0.510 \\
$1^{\text {st }}$ week & $8.17 \pm 0.68$ & $11.31 \pm 0.16$ & 1.63 & 0.020 \\
$2^{\text {nd }}$ week & $8.64 \pm 1.11$ & $11.84 \pm 0.46$ & 1.80 & 0.030 \\
$3^{\text {rd }}$ week & $10.44 \pm 0.14$ & $13.46 \pm 0.12$ & 0.31 & $<0.001$ \\
$4^{\text {th }}$ week & $9.85 \pm 0.23$ & $13.06 \pm 0.08$ & 0.53 & 0.009 \\
\hline Total daily milk per group (Kg) & & & & \\
One week before trial & $236.60 \pm 11.31$ & $257.04 \pm 8.6$ & 6.19 & 0.160 \\
$1^{\text {st }}$ week & $196.00 \pm 16.20$ & $271.50 \pm 3.86$ & 9.26 & 0.020 \\
$2^{\text {nd }}$ week & $207.40 \pm 26.60$ & $284.20 \pm 11.10$ & 17.69 & 0.020 \\
$3^{\text {rd }}$ week & $250.62 \pm 3.29$ & $323.10 \pm 3.88$ & 6.58 & $<0.001$ \\
$4^{\text {th }}$ week & $236.48 \pm 5.46$ & $313.44 \pm 2.00$ & 4.56 & 0.006 \\
\hline
\end{tabular}

RSD=Residual Standard Deviation.

Table 6: The mean values of Serum progesterone levels $(\mathrm{ng} / \mathrm{mL})$ of lactating pregnant low producing Friesian cows in response to control measures to alleviate heat stress.

\begin{tabular}{lcccc}
\hline Serum P4 (ng/mL) & Control group & Adapted group & RSD & P value \\
\hline One week before trial & $4.09 \pm 0.41$ & $4.93 \pm 0.32$ & 1.97 & 0.120 \\
$1^{\text {st }}$ week & $4.46 \pm 0.49$ & $4.06 \pm 0.23$ & 2.45 & 0.470 \\
$2^{\text {nd }}$ week & $4.65 \pm 0.51$ & $5.23 \pm 0.27$ & 2.18 & 0.340 \\
$3^{\text {rd }}$ week & $4.67 \pm 0.39$ & $6.45 \pm 0.20$ & 1.84 & $<0.001$ \\
$4^{\text {th }}$ week & $5.06 \pm 0.30$ & $6.34 \pm 0.22$ & 1.41 & 0.001 \\
Overall & $4.71 \pm 0.21$ & $5.52 \pm 0.15$ & & 0.002 \\
\hline
\end{tabular}

RSD=Residual Standard Deviation.

\section{DISSCUSION}

In the present study, heat stress had negative impacts on RT and RR of examined dairy cows which increased at both $\mathrm{mTHI}$ values $72-78$ and $>78$. These results were in accordance with (Spiers et al., 2004). It was found that a $1.5{ }^{\circ} \mathrm{C}$ rise of RT could be associated with reduction in performance. Moreover, RR increases with increasing THI and AT (Kendall et al., 2007; Schütz et al., 2008). This was attributed to failure of thermoregulation mechanism of animals to make balance between heat gain and heat loss in environment whereas AT exceeded the thermoneutral zone (TNZ). Cows responded to the environmental change by increasing their RR to get read of excess heat, as demonstrated previously (Morton et al., 2007). Average daily milk yield per cow was decreased in response to higher mTHI (above 72) and decrease was significant at mTHI $>78$ in this study. These results were in accordance with (Armstrong, 1994) who observed that dairy cows are beginning to be stressed when the THI exceeds 72 and exhibited a significant decline when maximum THI reached 77. In contrast, (Zimbelman et al., 2009) estimated that milk yield starts to decline when cows are exposed to a minimum THI of 65 or greater in highly producing cows. Moreover, milk production decreased by $0.2 \mathrm{~kg}$ per unit with the increasing value of THI >72 (Ravagnolo et al., 2000; West, 2003; Bohmanova et al., 2007; Cincovi and Beli, 2009). Milk yield was known to decline with increased RT but a more important factor to predict production losses has shown to be THI (Ravagnolo et al., 2000; West et al., 2003). The best recognized effect of heat stress on dairy cows is an adaptive depression of metabolic rate associated with reduced appetite (Silanikove, 2000). Heat stress causes the rostral cooling center of the hypothalamus to stimulate the medial satiety center which inhibits the lateral appetite center and consequently lowers milk production (Kadzere et al., 2002).

Postpartum cyclicity of examined cows was negatively affected by higher mTHI in the present study. In spite of that, postpartum cyclicity and cows having functioning corpus luteaum (CL) were not significantly influenced until mTHI was greater than 78 , a fact that low producing dairy cows are more tolerant to heat stress than high producing herd mates. Delayed postpartum cyclicity during high THI 
periods was reported previously by De Rensis and Scaramuzzi, (2003); Hansen, (2009). The absence of rise in metabolic heat production which is associated with the vast amount of milk synthesis in high producing cows might have been responsible for such results (Hansen, 2007). Heat stress early during the postpartum period reduced body condition score, folliculogenesis, dominant follicle diameter and altered the biochemical concentrations in the follicular fluid of the dominant follicle which might have resulted in inferior oocyte and granulosa cell quality, delayed postpartum cyclicity and hence poorer fertility of dairy cows (Palta et al., 1997; Shehab-El-Deen, 2011). In this investigation, the proportion of cyclic high P4 cows (having functioning $\mathrm{CL}$ ) was the highest at $\mathrm{mTHI}<72$ and reached its lowest value with mTHI increasing to $>78$. Additionally, there was a strong negative correlation $(\mathrm{r}=-0.88, \mathrm{P}<0.0001)$ between $\mathrm{mTHI}$ and serum concentrations of $\mathrm{P} 4$ obtained 5 days after insemination. Moreover, mTHI accounted for $77 \%$ of the variation in serum P4 concentrations five days after AI in examined cows. To the best of our knowledge, no studies have examined the relationship between serum P4 concentrations five days after artificial insemination (AI) and mTHI in low producing dairy cows. Previous studies performed on cows exposed to chronic heat stress - as in our study showed decreased circulating concentrations of P4 (Jonsson et al., 1997; Torres-Junior et al., 2008). In spite of that, P4 concentrations were increased in cows exposed to acute heat stress in other studies (Trout et al., 1998; Vaught et al., 1977). These differences were attributed to uncontrolled changes in other factors that affect blood P4 concentrations such as the type of heat stress (i.e. acute or chronic) and differences in dry matter intake or hepatic clearance of P4 (De Rensis and Scaramuzzi, 2003). The significant negative correlation between mTHI and serum $\mathrm{P} 4$ concentrations five days after AI might also explain the negative effects of adverse heat stress conditions on conception in cows, taking in consideration that significant pregnancy losses (approximately, 54\%) occur during the first five days after AI in cows (Hansen, 2011). Results also revealed that heat stress had detrimental effects on days to first estrus, days to first insemination, days to conception and number of inseminations per conception in dairy cows with significant effects obtained only at mTHI $>78$. These findings are in line with the tendencies observed in other studies (LopezGaitus, 2003; Morton et al., 2007; El-Wishy, 2013). Ovulatory failure (Lopez-Gaitus et al., 2005), impaired quality of oocyte or impaired embryo development, increased embryo mortality, endometrial dysfunction as well as reduced uterine blood flow under heat stress are possible causes involved in these findings (Wolfenson et al., 2000; Roth et al., 2001; De Rensis and Scaramuzzi, 2003).
Implementation of control measures in this study reduced the effects of heat stress on physiological parameters and milk production in adapted cows. Results were in agreement with previously reported results (Correa-Calderon et al., 2004; Valtorta and Gallardo, 2004; Kendall et al., 2007). Moreover, Silanikove et al. (2009) reported a $55.1 \%$ decrease in milk yield for heat stressed cows with no access to shade or other cooling whereas the reduction in milk yield for heat stressed cows but which had access to both shade and cooling by fans and sprinklers were $(7.9 \%)$. Other results verifying the impacts of heat on milk production were reported by Valtorta and Gallardo, (2004) who found that cooling before milking (by sprinklers and fan) resulted in higher milk yield. Cattle readily use shade when given access to it and the provision of shade can alleviate negative effects of increased heat load (Valtorta et al., 1997). Although it is clear that shade is beneficial and seems to be valuable to cattle, cooling with water, with or without fans, is more efficient in reducing heat load than is shade (Mitlohner et al., 2001; Correa-Calderon et al., 2004).

Control measures applied on lactating pregnant cows led to increased serum $\mathrm{P} 4$ concentrations with significantly higher $(\mathrm{P}<0.01)$ overall mean concentration in adapted cows as compared to control cows in the present study. This means that adapted pregnant cows succeeded to counteract the negative effects of chronic heat stress on luteal $\mathrm{P} 4$ production. Cows used in this trial were in mid-pregnancy, low yielding and thus were considered having no metabolic loads and also having lower rates of hepatic clearance of P4 governed by low dry matter intake. This might have been responsible for the significant increases in serum P4 levels in adapted cows. Moreover, adaptive measures were shown to increase cow comfort and reduce stressors where corticosteroids are known to suppress luteal production of P4 (De Rensis and Scarmuzzi, 2003).

These results concluded that heat stress negatively impacted milk production and fertility of low producing Friesian cows. Significant effects were observed with mTHI above 78. Moreover, we confirmed a strong negative correlation between mTHI and serum P4 in cows sampled five days postinsemination. We also concluded that control measures of lactating cows under moderate stress (mTHI between 75.36 and 78.8) based on multiple approaches led to increased milk production and serum P4 levels.

\section{ACKNOWLEDGMENTS}

Authors would like to thank full and acknowledge Prof. Dr. M.A. El Bably and Prof. Dr. EL Sayed Mahmoud Mohamed Abdel Gawad, Faculty of 
Veterinary Medicine Beni-Suef University for the technical support.

\section{REFERENCES}

Adams, R.; McCarl, B.; Segerson, K.; Rosenzweig, C.; Bryant, K.J.; Dixon, B.L.; Conner, R..; Evenson, R.E. and Ojima, D. (1999). The economic effects of climate change on US agriculture. In Mendelsohn, R \& Neumann, J (Eds), the Impact of Climate Change on the United States Economy. Cambridge University Press, Cambridge, UK. pp. 18-54.

Armstrong, D.V. (1994): Heat Stress Interaction with Shade and Cooling. J. Dairy Sci777July, 204422050022-0302.

Bohmanova, J.; Misztal, I. and Cole, J.B. (2007): Temperature-humidity indices as indicators of milk production losses due to heat stress. $J$. Dairy Sci. 90:1947-1956.

Cincovi, M.R. and Beli, B. (2009): Influence of thermal stress to milk production and quality in dairy cows. V.J.R.S .9(1): 53-56.

Correa-Calderon, A.; Armstrong, D.; Ray, D.; deNise, S.; Enns, M. and Howison, C. (2004): Thermoregulatory responses of Holstein and Brown Swiss heat stressed dairy cows to two different cooling systems. Int. J. Biometeorol. 48: $142-148$.

De Rensis, F. and Scaramuzzi, R.J. (2003): Heat stress and seasonal effects on reproduction in the dairy cow- a review. Theriogenology 60:1139-1151.

El Wishy, A.B. (2013): Fertility of Holstein cattle in a subtropical climate of Egypt. I.J.A.S. 3 (1): 45-51.

Hahn, G.L.; Mader, T.L. and Eigenberg, R.A. (2003): Perspective on development of thermal indices for animal studies and management. In: EAAP technical service no. 7, Interactions between climate and animal production. pp.31-44.

Hansen, P.J. (2007): Exploitation of genetic and physiological determinants of embryonic resistance to elevated temperature to improve embryonic survival in dairy cattle during heat stress. Theriogenology 68: 242-249.

Hansen, P.J. (2009): Effects of heat stress on mammalian reproduction. Philosophical Transactions of the Royal Society B. Bio. Sci. 364: 3341-3350.

Hansen, P.J. (2011): Challenges to fertility in dairy cattle: from ovulation to the fetal stage of pregnancy. Rev. Bras. Reprod. Anim., Belo Horizonte. 35 (2): 229-238.

Hasanean, H.M. (2008): Large-scale circulation anomaly indices in relation to very high temperature in Egypt during summer season 1998 (a case study). Int. J. meteorol. 33(327): 75-87.
Hisashi, N.; Hiroshi, O.; Toshihumi, N.; Tetsuo, M.; Koji, A. and Yasuhiro, T. (2011): Effect of the temperature-humidity index on body temperature and conception rate of lactating dairy cows in Southwestern Japan. Journal of Reproduction and Development. 57: 450-456.

IPCC, (2007): Climatechange: the physical science basis hTTP://WWW.IPCC/publications and datal publications IPCC fourth assessement report_wgl_report thephysical_science basi s.htm.

Jonsson, N.N.; McGowan, M.R.; McGuigan, K.; Davison, T.M.; Hussain, A.M. and Kafi, M. et al. (1997): Relationship among calving season, heat load, energy balance and postpartum ovulation of dairy cows in a subtropical environment. Anim. Rep. Sci. 47: 315-26.

Kadzere, C.T.; Murphy, M.R.; Silanikove, N. and Maltz, E. (2002): Heat Stress in Lactating Dairy Cows: a Review. Livest. Prod. Sci.771 October, 59911871-1413

Kendall, P.E.; Verkerk, G.A.; Webster, J.R. and Tucker, C.B. (2007): Sprinklers and shade cool cows and reduce insect avoidance behavior in pasture-based dairy systems. $J$. dairy sci. 90: 3671-3680.

Lopez-Gaitus, F. (2003): Is fertility declining in dairy cattle? A retrospective study in northeastern Spain. Theriogenology, 60: 8999.

Lopez-Gaitus, F.; Santolaria, P.; Mundet, I. and Yaniz, J. (2005): Walking activity at estrus and subsequent fertility in dairy cows. Theriogenology, 63: 1419-1429.

McCarthy, J.; Canziani, O.F.; Leary, N.A.; Dokken, D.J. and White, C. (Eds). (2001): Climate Change: impacts, adaptation, and vulnerability. Intergovernmental Panel on Climate Change (IPCC), Cambridge University Press, Cambridge, UK.

Mitlohner, F.M.; Morrow, J.L.; Dailey, J.W.; Wilson, S.C.; Galyean, M.L.; Miller, M.F. and McGlone, J.J. (2001): Shade and water misting effects on behavior, physiology, performance, and carcasstraits of heat-stressed feedlot cattle. J. Anim. Sci. 79: 2327-2335.

Morton, J.M.; Tranter, W.P.; Mayer, D.G. and Jonsson, N.N. (2007): Effects of environmental heat on conception rate in lactating dairy cows: critical periods of exposure. J. Dairy Sci.90: 2271-2278.

Ouweltjes, W.; Smolders, E.A.A.; Van Eldik, P.; Elving, L. and Schuken, Y.H. (1996): Herd fertility parameters in relation to milk production in dairy cattle. Livest. Prod. Sci. 46: 221.

Ozturk, O.A.; Cirit, U.; Baran, A. and Ak, K. (2010): Is Doublesynch a new alternative for timed 
artificial insemination in anestrous dairy cows? Theriogenology, 73: 568-576.

Palta, P.; Mondal, S.; Prakas, B.S. and Madan, M.L. (1997): Peripheral inhibin levels in relation to climatic variations and stage of estrous cycle in buffalo (Bubalusbubalis). Theriogenology, 47: 898-995.

Pierre, N.R.; Cobanov, S.T.G. and Schnitkey, G. (2003): Economic Losses from Heat Stress by US Livestock Industries. J. Dairy Sci. 86E. Suppl., E52E770022-0302

Ravagnolo, O.; Misztal, I. and Hoogenboom, G. (2000): Genetic component of heat stress in dairy cattle, development of heat index function. J. Dairy Sci. 83: 2120-2125.

Roth, Z.; Arav, A.; Bor, A.; Zeron, Y.; Braw-Tal, R. and Wolfenson, D. (2001): Improvement of quality of oocytes collected in the autumn by enhanced removal of impaired follicles from previously heat-stressed cows. Reproduction 122: 737-744.

Sartori, R.; Sartor-Bergfelt, R.; Mertens, S.A.; Guenther, J.N.; Parrish, J.J. and Wiltbank, M.C. (2002): Fertilization and early embryonic development in heifers and lactating cows in summer and lactating and dry cows in winter. J. Dairy Sci. 85: 28032812.

Schutz, K.E.; Cox, N.R. and Matthews, L.R. (2008): How important is shade to dairy cattle? Choice between shade or lying following different levels of lying deprivation. Appl. Anim. Behav. Sci.114: 307-318.

Shehab-El-Deen, M.A.M.M. (2011): Effects of metabolic stressors and high temperature on oocyte and embryo quality in high yielding dairy cows. PhD, Department of Reproduction, Obstetrics and Herd Health, Salisburylaan 133, B-9820. Ghent University.

Silanikove, N.; Shapiro, F. and Shinder, D. (2009): Acute heat stress brings down milk secretion in dairy cows by up-regulating the activity of the milk-borne negative feedback regulatory system. BioMed Central Physiology. 9: 13.

Silanikove, N. (2000): Effects of heat stress on the welfare of extensively managed domestic ruminants. Livest. Prod. Sci 67: 1-18.

Spiers, D.E.; Spain, J.N.; Sampson, J.D. and Rhoads, R.P. (2004): Use of physiological parameters to predict milk yield and feed intake in heat-stressed dairy cows. Journal of Thermal Biology. 29: 759-764.
Torres-Júnior, J.R.S.; Pires, M.F.A.; de Sá, W.F.; Ferreira, A.M..; Viana, J.H.M.; Camargo, L.S.A.; Ramos, A.A.; Folhadella, I.M.; Polisseni, J.; Freitas, C.; Clemente, C.A.A.; SáFilho, M.F.; Paula-Lopes, F.F. and Baruselli, P.S. (2008): Effect of maternal heat-stress on follicular growth and oocyte competence in Bosindicus cattle. Theriogenology, 69: 155-166.

Trout, J.P.; McDowell, L.R. and Hansen, P.J. (1998): Characteristics of the oestrous cycle and antioxidant status of lactating Holstein cows exposed to stress. J. Dairy Sci.81: 124450.

Valtorta, S.E. and Gallardo, M.R. (2004): Evaporative cooling for Holstein dairy cows under grazing conditions. Int. J. Biometeorol. 48: 213-217.

Valtorta, S.E.; Leva, P.E. and Gallardo, M.R. (1997): Evaluation of different shades to improve dairy cattle well-being in Argentina. Int. J. Biometeorol. 41: 65-67.

Vaught, L.W.; Monty, D.W. and Foote, W.C. (1977): Effect of summer heat stress on serum LH and progesterone values in Holstein-Frisian cows in Arizona. Am. J. Vet. Res. 38:1027-3.

Vitali, A.; Segnalini, M.; Berocchi, L.; Bernabucci, U.; Nardone, A. and Lacetera, N. (2009): Seasonal pattern of mortality and relationships between mortality and temperature-humidity index in dairy cows. J. Dairy Sci. 92: 37813790.

West, J.W. (2003): Effect of Heat-Stress on Production in Dairy Cattle. J. Dairy Sci. 86: 2131-2144.

West, J.W.; Mullinix, B.G. and Bernard, J.K. (2003): Effects of hot, humid weather on milk temperature, dry matter intake, and milk yield of lactating dairy cows. J. Dairy Sci. 86: 232242

Wolfenson, D.; Roth, Z. and Meidan, R. (2000): Impaired reproduction in heat-stressed cattle: basic and applied aspects. Anim. Reprod. Sci. 60: 535-547.

Zimbelman, R.B.; Rhoads, R.P.; Rhoads, M.L.; Duff, G.C.; Baumgard, L.H. and Collier, R.J. (2009): A re-evaluation of the impact of temperature humidity index (THI) and black globe humidity index (BGHI) on milk production in high producing dairy cows. Proc. Southwest Nutr. Manag. Conf. Tempe, AZ. ARPAS, Savoy, IL. pp. 158-168. 


\section{استفلال نهج متعددة للتكيف والتخفيف من الآثار السلبية للإجهاد الحراري على إنتاج الحليب وخصوية الأبقار الفريزيان تحت الظروف الحقلية \\ أسعاء نادى محدد ، ربيع لطفى عبل العزبيز ، محمد معروف على زينهم}

Email: $\underline{\text { asmadel82@yahoo.com, asmaa.mohamed2@vet.bsu.edu.eg Assiut University web-site: } \underline{w w w . a u n . e d u . e g}}$

تم تصميم هذه الدراسة بهذف تقييم تأثير الإجهاد الحراري على أداء الأبقار الفريزيان منخفضة الإنتاج وتطبيق تجربة حقلية متعددة

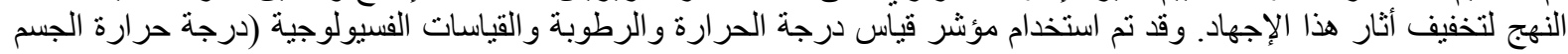

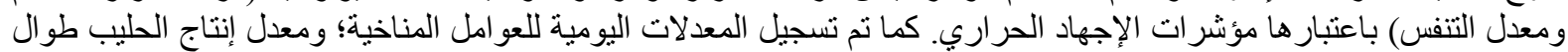

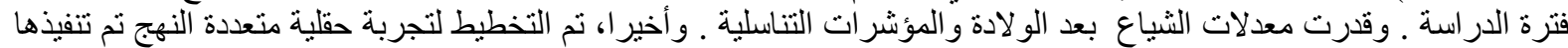

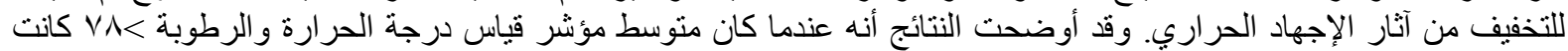

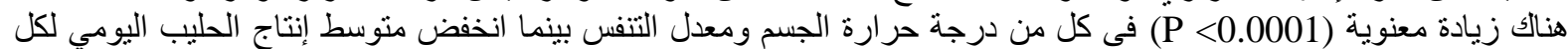

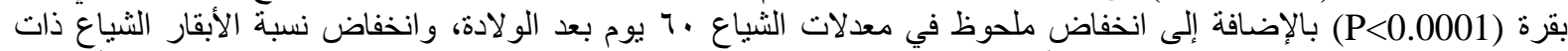

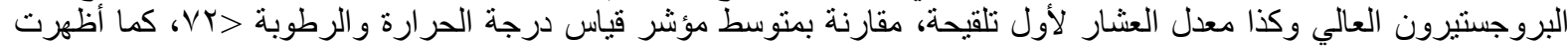

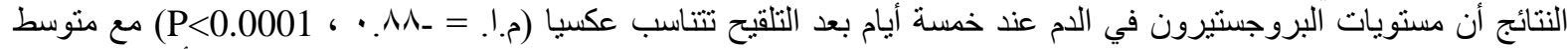

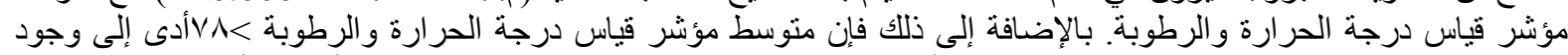

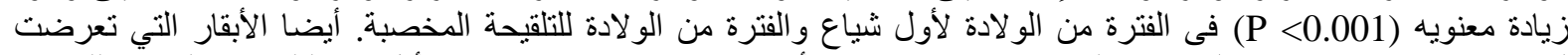

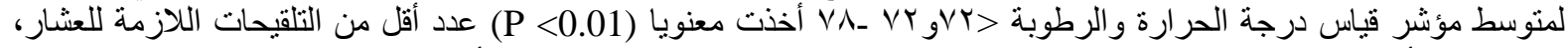

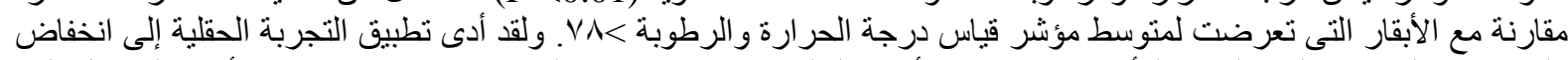

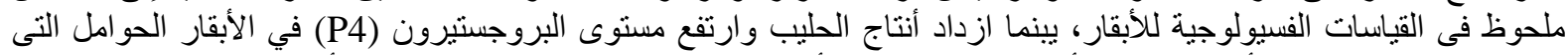

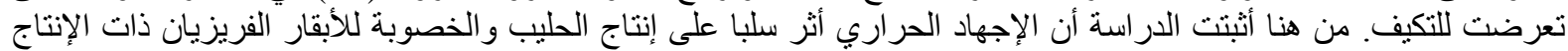

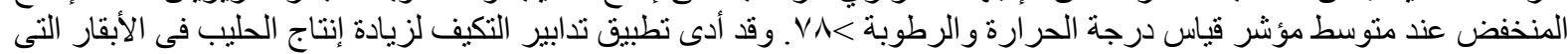

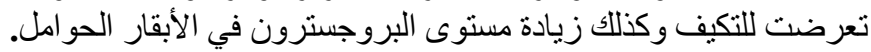

